\title{
Socio-Cultural Challenges of Women Development: The Case of Female Academics in Igbo land, Nigeria
}

\author{
Dr. Nkiru Christiana Ohia \\ Institute of African Studies, University of Nigeria, Nsukka; nkiru.ohia@unn.edu.ng

\section{Prof. Uchenna Mariastella Nzewi}

Department of Science Education, University of Nigeria,Nsukka; uchenna.nzewi@unn.edu.ng

\section{Doi:10.5901/mjss.2016.v7n1s1p269}

\section{Abstract}

The structures put in place to regulate the activities of men and women in Nigeria condition the programming of the mind of members of the society to the extent that the resulting subordination of women seems normal and acceptable, even to women themselves. With the changing policies and consequent emphasis on female education, the ground is shifting as many women have delved into the hitherto male domains and this includes Academics, but then, women still have to pass some sociocultural huddles to be able to attain a meaningful level of growth in their chosen carrier. This study reported in this paper adopts a qualitative and quantitative survey research design to identify some socio-cultural challenges faced by female academic staff in selected higher institutions in Igbo land. The design adopted for the study is a descriptive survey. A sample of 228 female academics staff across these five higher institutions in Igbo land within the age range of 25 to 65 were the study subjects. The instruments used for data collection were a 30-item open ended, semi-structured questionnaire titled Appraisal of SocioCultural Challenges of Female Academic Staff Development and an interview and Focus Group Discussion. Data collected from the questionnaire were analyzed using frequency and percentage, while those collected from the interview and focus group discussion were qualitatively analyzed. The study concluded among others that female academics experience difficulty balancing academic work and family responsibilities, attending conferences outside their base, staying back in the office after close of work.

Keywords: Women, development, education, culture, tradition.

\section{Introduction}

Education has been acknowledged as a major tool of women emancipation. Many studies, (Okobiah 2008, Foluke 2012, and Adiele and Mbachu 2011) have indicated that education is a panacea to women's development and emancipation. This is because according to Ibeneme, Alumode and Usoro (2012), education is the entire process of the development of an independent and integrated personality which encompasses training and acquisition of special skills, knowledge, attitudes and values needed to be responsible and which would enable him or her to contribute his or her own quota to the growth of the society. On the other hand, Fafunwa (1983b) avers that education is the vehicle by means of which the cultural heritage of a given society is transmitted to the younger generation. One of the major functions of education is to equip every member of the society with the knowledge that enlightens the intellect and strengthens the will. It is an instrument for development. In the words of Uchendu (1995), education does not only mean teaching people to know what they do not know, it also means teaching them to act, think and behave as they were not accustomed to act, think or behave before. It has the duty of conserving and transmitting appropriate cultural values as well as initiating changes where it is needed (Egbozor 2002). This is why education is an important instrument as it frees the educated from the shackles of ignorance, and changes his world view and status. Considering the benefits of education to the educated, it is expected that education will lead the way forward in the fight against cultural obstructions that hinder the struggle to achieveing modernity. Nigerian women are not represented in many fields of endevour in equal proportion with men. This could be attributed to the fact that the Europeans that brought education to Nigeria at first merely needed men who will be taught the three Rs so as to help them in their mission of evangelization. Supporting this view, Afigbo (2008) affirmed that Nigerian men had upper hand in education. This was characterized by the culture of being over protective towards their women. At that time parents preferred sending their male children to school in order to protect their daughters from the 'dangers and bad influence' of western education. Presently women are known to have succeeded in many fields that 
were previously seen as male reserve ( Fatokun and Idagboyi, 2010; Salami-Boukari, 2012,). Nigeria is one of the countries that have achieved the 35\% affirmative action on women involvement in appointive political posts, but then, they still have many huddles to cross (Afolabi and Arogundade 2003 ). Many women are now university professors, top medical doctors, laywers, engineers, and so on. Inspite of these, some highly educated women are still held down by many socio-cultural barriers which also hinder their not so well educated sisters. This is because there are some school based factors that encourage low intrest, poor participation, low aspiration and under-achievement in females. For example, a study by Owolabi and Onafowokan in Nzewi (2010) to determine gender representation in secondary school curriculum found that there is no gender ballance. In the nine selected textbooks reviewed for the study, seven had between I-9 female images while male images ranged from 2-50. Similar conclussions were made by Ali (2006) when he opined that the total school administration structure promoted different behaviours and expectations between boys and girls; leadership behaviours for boys were encoursged, promoted and patronized as against the case for girls whose leaderhip behaviours were found to be discouraged or even punished. He also noted that giftedness, unusual superior aptitudes and capacities displayed by girls in class are ignored, downplayed or discouraged, and seen as weird, deviant and the like. These challenges make it difficult for females to reach their full potentials even when they leave school.

In Nigeria as well as in other patriarchal African societies, there are inbuilt structures and stereotypes regulating the roles of women. These include the relegation of women and the sub-ordinate status and role expected of them. In a study to ascertain the impedements to women's career advancement, Mordi, Adedoyin and Ajonbadi (2011) identified these negative stereotypes to include women being only good to care for the home fronts, not being able to maintain a career, not ambitious, having less emotional stability, and possesing less strength. In addition women are expected to be submissive to men and are most often seen as sex objects. Having been socialised to see themselves in this light, some women do all they could to live up to the societal expectations of them. It is therefore not surprising that many female academics are not as pushful and determined as they are supposed to be. They have been made to believe that their first and major responsibility is the home and so some of them will be satisfied with just keeping the home front in order. This being the case, it appears that women who have large families will be weighed down more by family responsibilities.

On the other hand, there are some women who would want to make an impact but the negative stereotype that women (especilly married ones) should be under men becomes a problem. For example, culture stipulates that a married woman should obtain the consent of the husband before embarking on a journey. Some female academics have been known not to have attended conferences or other academic gatherings outside their places of residence just because their husbands did not permit them to travel. It appears that older academics both in rank and age, and whose children have grown do not have so many of such challenges. Also the unmarried, divorced, seperated and widowed academics may not be experiencing many challenges. Akinsanya (2012) stated that for the married woman, no matter the level of education she has attained, she can only rise as high and as fast as it is convenient for the husband and the home. This is because participation in conferences and seminars which are necessary complements and supplements for a successful academic career may be out of the question if the timing is inconvenient for the women due to her "primary responsibilities."

University campuses are a reflection of the larger society as social relationships are bound to take place. In most universities, some formal and informal networks like staff club exist. Although women are not denied membership of these social networks, their cultural role expectations as wives and mothers make it difficult for them to feature well in these circles. These social networks are strong socio-political networks in university campuses. Many decisions are made here and friendships are established. According to Lewis (2006), men and a few women who are part of these networks earn more promotions and advance faster in their jobs than people who are not members. This may not be due to any special favoritism but because in such informal settings, useful tips that improve job performances and advancement are obtained. Mentoring in academics is very crucial as younger academics learn the rudiments of the career from older and more experienced colleagues. As there are more male academics than females in most universities, female academics may sometimes be faced with the problem of amorous male mentors who see every woman as a sex object, and who turn out to be nasty when their sexual advances are bluffed. On the other hand, women themselves, may not like to have the very close relationship that mentoring demands with men who are not their husbands. Unmarried female academics may not have this problem in the same proportion since they have no husbands to be accountable to. This scenerio, however, is not perculiar to Nigerian universities. While lamenting the socio-cultural barriers that women academics in Kenya have to cross, Onsongo (2006) revealed that work environment is unfriendly for women academics in Kenyan Universities as senior female lecturers experience resistance from junior and senior male colleagues, most meetings are scheduled at odd hours, and there is rampant sexual harassment of female lecturers. In the same vein, in a study to investigate gender and promotions in higher education in University of Education, Winneba, Ghana, Oforiwaa and AffulBroni (2014) are of the view that while some lip service is paid to gender equity in the University, there is not much going 


\section{on to support and encourage it.}

Since universities influence and are influenced by the culture of the societies in which they are established, there is no gainsaying that there may be socio-cultural challenges facing female academic staff in universities. The main purpose of this study therefore is to identify the socio-culcural challenges facing female academic staff of higher institutions in Igbo land. The specific purpose which are derived from this main objective are to find out

- the socio-cultural challenges experienced by female academic staff in higher institutions in Igboland.

- if rank determines how socio-cultural challenges impact on the career prospects of female academic staff of higher institutions in Igboland.

- if age determines how the socio-cultural challenges impact on the career prospects of female academic staff of Higher institutions in Igboland.

The research questions that guided the study are:

1) What are the socio-cultural challenges experienced by female academic staff in higher institutions in Igboland?

2) Does rank determine how the socio-cultural challenges impact on the career prospects of female academic staff in higher institutions in Igboland?

3) Is age a determinant of the impact of socio-cultural challenges on the career prospects of female academic staff in higher institutions in Igboland?

\section{Theoretical Framework}

The theoretical explanation of this study is anchored on theory of Social Exclusion. Social Exclusion has been defined by Silvery in Okeke (2010) as the process through which individuals or groups are wholly or partially excluded from full participation in the society in which they live. Okeke (2010) avers that in contrast to poverty and unemployment which focus on individuals or households, social exclusion is primarily concerned with the relationship between the individual and society, and the dynamics of that relationship. On the other hand, Duffy (1995) see social exclusion as the inability to participate effectively in economic, social, and cultural life and, in some characteristics, alienation and distanced from mainstream society. This definition by Duffy aptly describes the exclusion of female academic staff in the sense that while they are members of the academia, they are not able to participate effectively as a result of the socio-cultural impediments they have to put up with either as mothers or wives. They are either expected to interrupt their employment or reduce their working periods due to family exigencies

Klasen (1997) opined that one can see social exclusion among non-disabled groups as socially generated barriers that reduce the ability of the excluded individuals to interact with society, but even when the barriers are no longer active, the excluded could still be held down by socialization and negative stereotyping to the extent that when all the conditions necessary for inclusion are put in place, the excluded will still see himself as not being good enough, or may feel that he is going contrary to expectations, and so refuses to avail himself of the opportunity to be included. For example, Mordi, Adedoyin and Ajonbadi (2011:18 ) in a study to ascertain the impedements to women's career reported the follwing responses from a woman

I am not too keen in being a senior manager, let's leave that role for men. I am happy with my role in the company. If I become the overall boss in the company, I will not be able to cope with the family, kids, husband, and relatives; and you know that is a recipe for disaster. I think culturally even in the church and mosques we are taught that men are the head, they are better at these things. In Nigeria we are not really prepared for female leaders of industry. We still have a long way to go. Imagine, in just this little position of authority, I went through a lot of challenges. As a woman, keeping a job and the home is challenging, except for a supportive husband and relations.

Laying credence to the above view, Agbalajobi (2010) posits that social exclusion of women has its roots in the nature of our societies which celebrate men as being unique, stronger, and fit for the public space while women are seen as feeble and weak and meant to stay within the confines of the private space. The result of this state of affairs is that even female academics who know that membership of staff clubs, and attending conferences, for example, are capable of boosting their networks, they are reluctant to belong so as not to offend public sensibilities or to avoid labeling.

According to Duffy (1995) and Oreh (2014), social exclusion relates not only to lack of material resources,but also to matters like inadequate social participation, lack of cultural and educational capital,inadequate access to services, and lack of power. Thus, female academics in Igboland are excluded and restricted by culture and tradition from taking full advantage of the oppurtunities that help to make better and stronger academics. 


\section{Research Method}

The design adopted for the study is a descriptive survey. The study was carried out in five higher institutions in Igbo land (South-East Nigeria), these are: University of Nigeria, Nsukka, Enugu State; University of Science and Technology, Enugu, Enugu State; Imo State university, Owerri, Imo State; Federal College of Education Technical Umunze, Anambra State; Federal University of Agriculture, Umudike, Abia State. The choice of this zone is informed by the fact that women of South-East Nigeria (Igbo Women), and especially those from the states selected are adjudged to be among the most well educated women in the Nigeria, even to the extent that there is the expressed concern that they out number men in the higher education sector.

A sample of 228 female academics staff across these five higher institutions in Igbo land within the age range of 25 to 65 were the study subjects. These respondents were reached by 5 female post graduate students who were used as research assistants. They were asked to administer the instrument on the female academic that they can reach within the institutions assigned to them. The demograghic characteristics of the study subjects are specified in Table 1.

Table 1. Demographic characteristics of the sampled female academic staff.

\begin{tabular}{|l|c|}
\hline Variable & Frequency/Percentage \\
\hline Rank of staff & 48 \\
\hline Assistant Lecturer / Assistant Research Fellow & 88 \\
\hline Lecturer 11/Research Fellow 11 & 52 \\
\hline Lecturer 1/Research Fellow 1 & 32 \\
\hline Senior Lecturer/Senoir Research Fellow & 8 \\
\hline Reader /Professor & 228 \\
\hline Total & \multicolumn{2}{|l|}{} \\
\hline Age & 52 \\
\hline $25-35$ & 76 \\
\hline $36-45$ & 92 \\
\hline $46-55$ & 8 \\
\hline $56-65$ & - \\
\hline 65 and above & 228 \\
\hline Total & \\
\hline
\end{tabular}

The instruments used for data collection were a 30-item open ended, semi-structured questionnaire titled Appraisal of Socio-Cultural Challenges of Female Academic Staff Development and an interview and Focus Group Discussion (FGD) protocol which elicited further comments from the respondents and also enabled researchers to probe further on some of the open-ended issues raised. The format of the questionnaire made it possible for the female academics who were neither available to be interviewed nor had time for the focus group discussion to express their views on all aspects of the issues under discussion. While data collected from the questionnaire were analyzed using frequency and percentage, that collected from the interview and focus group discussion were qualitatively analyzed.

\section{Results}

Data in Tables 2 and 3 indicate the socio-cultural challenges faced by female academics in the higher institutions visited according to their rank, that is, their academic status and their biological age. Other challenges that came up from the interview with a select few and the FGDs are discussed qualitatively.

Table 2: Socio-cultural challenges faced by female academics in higher institutions in Igbo land by Academic rank

\begin{tabular}{|c|l|c|c|c|c|}
\hline \multirow{2}{*}{ S/No } & \multirow{2}{*}{ Socio-Cultural Challenges } & \multicolumn{3}{|c|}{ Responses by rank (frequency/\%) } \\
\cline { 3 - 5 } & & Junior & Middle & Senior & Total \\
\hline 1 & Difficulty in balancing academic work and family responsibilities & $132(57.90)$ & $8(3.5)$ & - & $140(61.40)$ \\
\hline 2 & House hold chores & $96(42.10)$ & $4(1.75)$ & - & $100(43.86)$ \\
\hline 3 & Attending to visitors & $96(42.10)$ & $4(1.75)$ & - & $100(43.86)$ \\
\hline 4 & Attending to children (schooling, assignments, care) & $116(50.88)$ & - & - & $116(50.88)$ \\
\hline 5 & Attending to husband & $48(21.05)$ & - & - & $48(21.05)$ \\
\hline
\end{tabular}




\begin{tabular}{|c|l|c|c|c|c|}
\hline 6 & Inability to stay back in office after hours & $84(36.84)$ & $20(8.77)$ & $8(3.5)$ & $112(49.12)$ \\
\hline 7 & Non-attending to conferences outside base & $112(49.12)$ & $8(3.5)$ & - & $120(52.63)$ \\
\hline 8 & Non cooperating husbands/Feeling threatened & $48(21.05)$ & - & - & $48(21.05)$ \\
\hline 9 & Extended family interference & $48(21.05)$ & $12(5.26)$ & - & $60(26.32)$ \\
\hline 10 & Social events/activities (Meetings, weddings etc) & $96(42.10)$ & $28(12.28)$ & $8(3.5)$ & $132(57.90)$ \\
\hline 11 & Non-membership of research team/group & $60(26.32)$ & - & - & $60(26.32)$ \\
\hline 12 & Non -membership/attendance to staff club & $128(56.14)$ & $20(8.77)$ & - & $148(64.92)$ \\
\hline 13 & Compulsory attendance to family burials & $52(22.81)$ & $16(7.01)$ & $8(3.5)$ & $76(33.33)$ \\
\hline
\end{tabular}

Legend: Junior Academics - Assistant lecturers/Lecturers 1 and 11

Middle Academics - Senior Lecturers

Senior Academics - Professorial cadre (Associate and full)

Table 3: Socio-cultural challenges faced by female academics in higher institutions in Igbo land by biological age

\begin{tabular}{|c|l|c|c|c|c|c|}
\hline \multirow{2}{*}{ S/No } & Socio-Cultural Challenges & \multicolumn{3}{|c|}{ Responses by biological age in years (frequency/\%) } \\
\cline { 2 - 7 } & $\mathbf{2 5 - 3 5}$ & $36-45$ & $46-55$ & $\mathbf{5 6 - 6 5}$ & Total \\
\hline 1 & Difficulty in balancing academic work and family responsibilities & $56(25.56)$ & $44(19.30)$ & $40(17.54)$ & - & $140(61.40)$ \\
\hline 2 & House hold chores & $44(19.30$ & $28(12.28)$ & $28(12.28)$ & - & $100(43.86)$ \\
\hline 3 & Attending to visitors & $44(19.30$ & $30(13.16)$ & $26(11.40)$ & - & $100(43.86)$ \\
\hline 4 & Attending to children (schooling, assignments, care) & $44(19.30)$ & $50(21.93)$ & $22(9.65)$ & - & $116(50.88)$ \\
\hline 5 & Attending to husband & $16(7.01)$ & $16(7.01)$ & $16(7.01)$ & - & $48(21.05)$ \\
\hline 6 & Inability to stay back in office after hours & $46(20.18)$ & $32(14.04)$ & $30(13.16)$ & $4(1.75)$ & $112(49.12)$ \\
\hline 7 & Non-attending to conferences outside base & $80(35.09)$ & $30(13.16)$ & $10(4.39)$ & - & $120(52.63)$ \\
\hline 8 & Non-cooperating husbands / Feeling threatened & $24(10.53)$ & $16(7.01)$ & $8(3.50)$ & - & $48(21.05)$ \\
\hline 9 & Extended family interference & $34(14.91)$ & $18(7.90)$ & $4(1.75)$ & - & $60(26.32)$ \\
\hline 10 & Social events/activities (Meetings, weddings etc) & $92(40.35)$ & $26(11.40)$ & $14(6.14)$ & $2(0.88)$ & $132(57.90)$ \\
\hline 11 & Non-membership of research team/group & $34(14.91)$ & $18(7.90)$ & $8(3.51)$ & - & $60(26,32)$ \\
\hline 12 & Non-membership/attendance to staff club & $68(29.82)$ & $56(24.56)$ & $24(10.53)$ & - & $148(64.92)$ \\
\hline 13 & Compulsory attendance to family burials & $28(12.28)$ & $28(12.28)$ & $16(7.01)$ & $4(1.75)$ & $76(33.33)$ \\
\hline
\end{tabular}

\section{Findings and Discussions}

Data in Tables 2 and 3 reveal that the socio-cultural challenges that impact more on female Academics irrespective of rank and age include difficulty in balancing academic work and family responsibilities (64.92\%); the need and expectation to attend Social events/activities (such as town union meetings, weddings etc) (57.90); Inability to attend conferences outside their base due to several reasons which include husbands refusal (52.63\%); taking care of their children's need which include cooking for them, taking them to and from school and helping them in their assignments (50.88\%); Non membership/attendance to staff club (64.92\%); and inability to stay back in the office after close of work (49.12\%).

\subsection{Difficulty in balancing academic work and family responsibilities}

Female academics indicated balancing academic work and family responsibilities as one of the socio-cultural challenges they face as Academics. The family responsibilities include doing household chores (cleaning, laundry, cooking etc), shopping for the family needs, preparing and taking their children to school and also helping them with their homework and assignments. It also includes taking care of their husbands' needs and attending to them.

Of the $61.40 \%$ of the respondents who indicated difficulty in balancing academic work and family responsibilities, $52.90 \%$ are junior academics of the rank of lecturer one and below, and they belong to three distinct age range of 25-35 (25.56\%), 36-45 (19.30\%) and 46-55 (17.54\%). This finding is expected because these academics are still within the child bearing age, have school aged children and are probably not fully established in their marriages. They are thus still tied down by a lot of stereotypes. During the FGD, the younger academics within the age bracket 25-45 complained that taking care of their children is not as problematic as taking care of her husband. In the words of one of the ladies:

Once you give the children their food when they come back from school and help them do their assignments, you can get them to go and play while you take care of some academic work. My greatest problem is my husband who will come in at an odd hours and expect to be waited on hand and foot. Sometimes he may even reject the already cooked meal thereby making me to go back to the kitchen when I thought I had finished with the kitchen for the day. I find this 
very frustrating and at the end of the day, I will be too tired to do any academic work.

When we tried to find out from both the interview and FGD if there are some types of men are more prone to adding to the stress, we found out that women who are not married to Academic staff are usually more affected. One of the ladies revealed that the last thing her husband will do is to collect his meal from the kitchen or return his plate to the kitchen after a meal, thus adding to her stress, especially given the fact that he comes home at odd times, never keeps to the family meal times and thus adds extra burden to her, especially on days he comes back very late. She added that her husband will always remind her that "he did not help her get that job so that she will stop playing her wifely and motherly roles; and that she should see her lecturing job as changing from teaching in a secondary school, to teaching in a university and so should stop putting on airs of paper writing and conference attendance and all such stuff. This finding is collaborated by Anugwom (2009) when he observed that as a result of the patriarchal nature of the Nigerian society, men are usually more likely to see their wives first and foremost as homemakers rather than fellow workers and partners in development. Sometimes, husbands who are not well educated create extra difficulties for their wives to boost their egos as most of them often boast to their associates that although they are not university lecturers that they have one in the house who they control. This has led to a situation whereby many women academics despite their zeal to excel have been stagnated due to their husbands uncooperative attitude. The surprising aspect of this finding is that some male academics are no better when it comes to uncooperative attitudes.

As one of the discussants whose husband is an academic remarked during the FGD that:

You have to realise that men, whether academics or not are more jealous than women. The moment your aspirations increase and become evident, chances are that your husband might start being funny. As soon as I changed from teaching in a secondary school to the university, my husband will not say anything without using the cutting remark "now that everybody is a lecturer in this house..."So tell me, how can one's aspirations see the light of day with such a jealous husband?

This is not perculiar to female academics in Nigeria. While lamenting her plight as a female academic in a Ghana University, a respondent in Oforiwaa and Afful-Broni (2014) observed that the task of combining motherhood with academic life was challenging for most women, and militates against their career development, rather, it favours male career trajectories. Infact, all the frmale respondents in the study indicated that motherhood and other domestic responsibilities are incompatible with academic career, as the institutional practices represent both cultural stereotyping, material and intellectual oppression which result in many Ghananian universities remaining masculine in terms of representation, decision making procedures and the culture of their members.

\subsection{Inability to attend conferences outside their base due to several reasons which include husbands refusal}

One hundred and twenty (120) respondents representing 52.63\% indicated that they have never attended any conference outside their institutions' base. Of this percentage, junior academics make up $49.12 \%$. Their reasons ranged from husbands refusal to not knowing how to handle her children in their absence. The age range mostly affected by this are: $25-35$ (35.5\%); 36-45 (13.16\%). Here again, age and rank play a big role as those who are more affected are those lecturers who are still in the child bearing age and are not yet so well established in their marriages as to take personal decisions as regards their movements. This, according to Fapohunda as cited by Anugwom (2009), is especially difficult for young mothers as they lack the support networks which mothers, grand mothers or other extended family members provided in traditional settings. Although support could be received from paid domestic help, it is most times fraught with difficulties. One of the respondents identified the difficulties associated with helps as:

...one may leave the family in the hands of a domestic help and travel for a conference only to come back to see that the help has not taken care of the baby, or in some cases may have taken over one's husband

For a young female academics, this is a real cause for concern as not attending conferences for self improvement is bad enough on her career and adding that to the possibility of losing her husband and family to another woman, makes it a double jeopardy. No wonder Akinsanya (2012) opined that it is very probable that the actualization of every married woman's dream on the job is a function of the cooperation given her by her spouse, family members and her state as a woman. Some women have very supportive husbands who take joy and pride in their family growth and are therefore not at any disadvantage. 


\subsection{Inability to stay back in the office after close of work}

One hundred and twelve respondents (112) representing $49.12 \%$ indicated their inability to stay back in the office after work to do personal work and attend to their students. Of this, $36.84 \%$ are junoir accademics, $8 \%$ are middle level while $3.5 \%$ are senior academics. Although they know the advantages of staying back to do personal work after official hours, and that they could only do very little academic work at home considering the enormous work load at home ,they could still not stay back after close of work. Their reasons range from husbands frowning at staying out late, to infringing on the time for children's home work and other family chores. The academic profession requires a huge investment in time and energy. You either perform or you are out. In support of the above, Tetty (2010) observed that academic institutions have masculinist institutional cultures and women academics are increasingly under pressure to perform in this masculine environment. This is compounded by the fact that in addition to heavy work-load which they have to juggle with family responsibilities, they have limited extra time to function maximally as academics. This fact is supported by The fact that very few respondents in the senior cadre (3.5) are faced with the problem of staying back after work suggests that either they are approaching the apex of their careers and need to slow down, since they are mostly in the age range that no longer have growing children and working at home will no longer be a problem, or that their spouses' demands on them are no longer as intense, and they could therefore go and come as they please.

\subsection{Non-membership/attendance to staff club}

Data on Tables 2 and 3 indicate that many female academics do not belong to staff clubs. From Table 2, 56.14\% of junior academics and $8.77 \%$ of middle academics are not members/do not go to the staff club; while from Table $3,29.82 \%$ of those between the ages of $25-35 ; 24.56 \%$ in the age range of $36-45$, and $10.53 \%$ of those between 46 to 55 years are not members of staff club. In all, $64.92 \%$ of all the respondents are not members of the institutions' staff club. The age range and rank of the females that do not use the opportunity provided by the staff clubs are actually those that need it more. The reasons they proffered for their non-membership include that their husbands are registered members and club registration is a family registration. When asked whether they go to the club, the response pattern remained the same and the reasons they gave for this include that men have wrong impression of women who visit the club, and that their husbands may not approve of their going especially if such husbands do not go often; some of them claim that they do not have the time due to family responsibilities among others. Many of these respondents do not see anything wrong in going to the club to unwind after a day's work and also benefit from information sharing and informal assistance from colleagues, but because men do not readily approve of women at the club, they have most times been willing to conform to the wrong stereotypes. These women thus miss out on a major social network that exists in their institution and which may be to their disadvantage. Lewis (2006), had observed that men and a few women who are part of these networks earn more promotions and advance faster in their jobs than people who are not members. This lack of social network is a therefore a big challenge to female academics because men use these unofficial networks to learn from colleagues and get a helping hand when necessary. Rubery (2004) sees this as another great obstacle to career growth of women academics. This has persisted because many women approach the work place with the wrong psychological disposition, in their desire not to strive to prove the men wrong and so display attitudes and work orientations that show them exactly as the men wish them to be.

\subsection{The need and expectation to attend Social events/activities (such as town union meetings, weddings, etc)}

Female academics indicated the need and expectation to attend social events and activities as one of the challenges they face as university teachers. All the respondents in this study are members of different women socio-cultural groups in their communities, mostly the Umuada (a socio-political group of all the females born in a particular kindred) and Inyomdi (a socio-political group of all the women married to a particular kindred), in addition to being members of Christian Women organisations. The Igbo society is noted as one where everybody is his or her brother's keeper and so, whether in good or bad events, friends, relatives and well wishers are expected to identify with each other hence the maxims "onye aghala nwanne ya and igwe bu ike" (everybody should stand by a relative in times of need). The republican nature of the Igbo society makes it necessary for one to take part in many social functions and these take its toll on one's time and energy. As female academics, it is not always easy to have time for most of the social functions. In support of the above notion, Akinsanya (2012) noted that in addition to the work and domestic pressure confronting women academics, they are also faced with the limited extra time to join efforts with other women groups and it is not, therefore, suprising that sometimes women academics are shunned by their fellow women and are seen as uncaring or unconcerned or seen 
as people putting on airs of superiority. Narating her ordeals as a result of difficulty in attending social and cultural functions, one of the respondents had this to say:

When my father-in-law died in 2008, I informed the Inyomdi in our traditional manner, by presenting drinks and soliciting their help and support during the burial. They accepted what I offered but unknown to me, they had grudges against me because I had not been regular in attending burails and other meetings with the Inyomdi due to the nature of my work. I was depending on them to clean the compound every morning as we usually do help in other ways they could, such as serving visitors and generally keeping the compound tidy. I did not know they had a meeting after I had left saying that any member that came to help me will be fined. Fortunately, I had a large number of my friends and students with me and they were able to fill in the gap before I arranged for paid help. I would have had the greatest shock of my life because the Inyomdi was bent on "punishing" me for not attending most social functions with them as I should.

In most Igbo land, it is the duty of Inyomdi to cook during burials or other celebrations within the kindred, but the practice is now becoming obsolete as a result of the availability of commercial event handlers; the Inyomdi (a sociopolitical group of all the women married to a particular kindred) still helps in cooking especially in low income families and they are still largely responsible for tidying the compound before visitors begin to arrive, especially during burials. It is such responsibilities that contribute to the additional stress experienced by female academics in Igbo land.

\section{The Way Forward}

In discussing the way forward, the researchers want to look at the coping strategies worked out by the few women who stated that they do not have any of the challenges faced by majority of the women or that they have been able to overcome them.

On the difficulty in balancing academic work and family responsibilities, the women who have overcome this challenge stated that they succeeded through subtle negotiations with their husbands. Some of them stated that they had to use part of their salary to pay for part time helps like house cleaners, laundry men, drivers and private teachers for their children. These made it possible for them to be involved in only supervision work which is less cumbersome. One of the senior academics had this advice to offer the younger ones:

Men are like babies. They like to be in-charge and want to be seen to be in-charge. Once you plan your life and you have an idea of how you want your home to run, suggest it to your husband after you have done your homework. Don't press home your point. At a later date, bring up the issue for discussion, you will now find that he will throw out those your ideas as if they were his own. All you have to do is agree to them and start implementation. By so doing, you save yourself from unnecessary arguments.

Some of the senior academics in sharing their story revealed that inability to attend conferences outside their base due to several reasons which include husbands' refusal was a problem to them initially but they were able to get through by starting with local conferences, then conferences which they attend as a group with other female academics. One of them stated that if you have never presented a paper at a local conference and suddenly you want to travel out for a conference, you will definitely cause raised eyebrows. Another stated that she gets close relations to stay with her family and in her absence such relations take care of her family. Others said that they involve their husbands in the children's life. One of the ladies narrated how she used subtle blackmail to get her husband who is a Professor of Mathematics to start being involved in their children's homework by reminding him that it will be shameful to have children of a Professor of Mathematics failing the subject. This made her husband get involved and from Mathematics he started teaching the children other subjects and also started spending time with them. This scenario made it possible for her to attend conferences outside the home since the husband has become "domesticated". One of them concluded that in the final analysis, it is a matter of one earning the trust of her husband. Her words:

If you have never given your husband cause to suspect you of infidelity, I am not sure he is going to use that excuse to prevent you from attending a conference. It is therefore important that as a young female academic, you comport yourself well so that your husband can trust you out of his sight.

Inability to stay back in the office after close of work was not considered a big deal by the ladies who do not see it as a problem. They suggested staying up late or getting up earlier than other family members as viable alternatives. One of the female professors interviewed stated that she had never stayed back in the office after her lecturers, and that the only time she stays back is when she has evening lectures. She claimed that once she is not attending to students or having lectures and has up to two hours before her next scheduled activity, that she drives home to work at home.(She was able to do this because she lives 5 driving minutes away from her office). The bottom line in all the suggestions proffered is planning. 
Non -membership/attendance to staff club is another point considered a non-issue by the more senior academics. They reasoned that you can always reach the lecturers in their office. Another suggested going to the club in the afternoon during lunch break and pointed out that not all the men go to the club after close of work, and added that some spend their lunch hour at the club. They therefore advised ladies who have issues with going to the club to arrange meetings with their colleagues during office hours and that such meetings will not cause any stir even if it holds in the club. Female academics were also advised to attend non-club events that take place in and outside the club as it can also be useful networking opportunities.

The senior academics stated that with globalization and advances in society, the need and expectation to attend social events/activities (such as town union meetings, weddings, etc) is no longer as severe as it used to be. This is because some of the duties performed by these groups in the past e.g. cooking and helping out at family events are available commercially and may usually be less stressful. They therefore advised the junior academics to attend such meetings when they can and ensure that some of those expectations that tie them down are removed from the byelaws of the associations and groups. They also advised that these meetings and get-togethers should be seen as relaxing outings and one in which every attendee should learn something new. By so doing, every woman member of the group will see the outings as something not to be missed and the issue of using non-attendance as an opportunity to deny one of certain rights and privileges will not arise.

\section{Conclusion}

Female academics experience difficulty in the following areas:

- balancing academic work and family responsibilities

- Inability to attend conferences outside their base due to several reasons which include husbands refusal

- Inability to stay back in the office after close of work

- Non-membership/attendance to staff club

These socio-cultural challenges are not insurmountable. Experience of women who had surmounted these challenges can be used by the upcoming ones to succeed.

\section{References}

Adiele, E. E. and A.A.Mbachu. 2011. Improved access to functional education: Promoting gender equality and women empowerment in Nigeria. Journal of International Gender Studies 7,no $1: 177-184$.

Afigbo, A.E. (2008). Igbo women in education. In Otagburuagu, E.J and Afigbo, A.E (eds) More Brides : New Hopes. Nsukka: Institute of African Studies, University of Nigeria, Nsukka

Afolabi, A.K and Arogundade, L ( 2003) Gender audit -2003 election and issues in women's political participation in Nigeria. Apublication of Women Advocates Research and Documentation Centre, Abuja.

Agbalajiobi, D.T. 2010. Women participation and political process in Nigeria: Problems and prospects. African Journal of Poiltical Science and International Relations 4 (2)75-83

Akinsanya, O. O. 2012..The role of women in academics: Issues,challenges and perspectives. JORIND 10:136-141.www.transcampus. org/journals.Retrieved 1/2/2013.

Ali, A. (2006). Growth and developmentin Africa: Perspective in gender equity. Education and Development, 9 (1) 18-24

Anugwom, E.E. 2009. Women education and work in Nigeria. Educational Research and Review 4,no 4: 127-134.

Duffy,K.1995. Social exclusion and human dignity in Europe.Strasbourg: Council of Europe.

Egbezor, D. E. 2002. Education and Socialization in Okeke ,E.C (ed) Sociology of Education. Owerri: Springfield Publishers Ltd.

Fatokun ,K and Idagboyi, I. (2010). Gender disparity and parental influence on secondary school achievement in Nasarawa State, Nigeria. Journal of Researcc in National Development 8 (2) 1-6

Foluke, F. 2012. Gender inequality in education : Implications for national development. Journal of The Nigerian Academy of Education 8 ,no 1:24 32

Ibeneme O, B.Alumode and H.Usoro. 2012. The state of education in Nigeria. Onitsha West and Solomon Publishing Company Limited.

Klasen. S.1997. Measuring poverty and deprivation in South Africa. Cambridge: University of Cambridge press

Lewis, P 2006. The quest for invisibility:Female entrepreneurs and the masculine norm of entreprenurship. Gender and Organization 13, no. : $623-646$.

Oforiwaa, O.and Afful-Broni A. (2014). Gender and promotions in higher education: A case study of the University of Education, Winneba, Ghana. International Journal of Education Learning and Development 2 (1) 34-47. www.ea-journals.org. Retrieved on 3rd February, 2015.

Okeke,B.A. 2010. Essentials of special education. Nsukka. Afro-Obis Publications Ltd

Okobia, O. C. 2008. The family and spouse abuse: A challenge to Nigerian counsellors.15th Inaugural Lecture of the Delta State University, Abraka. 
Oreh,C. 2014. Igbo cultural widowhood practices: reflections on inadvertent weapons of retrogression in community development.80th Inaugural Lecture of the University of Nigeria, Nsukka.

Onsongo, J. (2006). Gender inequalities in Universities in Kenya. In Creighton,C, and Yieke,F. (eds), Gender inequalities in Kenya. UNESCO

Owolabi, T. and Onofowokan, B. (2001) In Nzewi, U.M. (2010). It's all in the brain: Of gender and achievement in Science and Technology Education. 51st Inaugural Lecture of the University of Nigeria, Nsukka

Mordi C, A.Adedoyin and B.Ajonbadi. 2011. Impediments to women career advancement: The Nigerian experience. Petroleum-Gas University of Ploiesti Bulletin 63,no.2:11-22.

Rubery ,J. (2004) Gender Mainstreaming and Women's Employability in EU countries. www.unece.org. Accessed: 5th March 2009.

Salami-Boukari, S. (2012). African Literature : Gender discourse,religious values, and the African worldview. New York: African Heritage Press.

Tetty, W.J.2010. Challenges of developing and retaining the next generation of academics: Deficits in academic staff capacity at African Universities. http: //hopesforwomen.org/challenging-gender-based-discrimination, Retrieved 28th September,2013

Uchendu P. K. 1995. The role of Nigerian women in politics. Enugu: Fourth Dimension Publishing Co. Ltd. 